\title{
Electronic visualization tools in education
}

\section{Herramientas de visualización electrónica en educación}

\author{
Yana V. Zubkova \\ ZubkovaYaV@mgpu.ru \\ https://orcid.org/0000-0002-2484-7316 \\ Moscow City University, Moscow, Russia. \\ Julia O. Baikina \\ https://orcid.org/0000-0002-3874-3665 \\ Federal State Budget Educational Institution of Higher Education «Industrial University \\ of Tyumen», Tyumen, Russia. \\ Svetlana V. Sergeeva \\ sergeeva@penzgtu.ru \\ https://orcid.org/0000-0002-3612-3112 \\ Penza State Technological University, Penza, Russia. \\ Irina Y. Burkhanova \\ irina2692007@yandex.ru \\ https://orcid.org/0000-0002-7954-2341 \\ Minin Nizhny Novgorod State Pedagogical University, Nizhny Novgorod, Russia. \\ Margarita I. Koldina \\ ritius@mail.ru \\ https://orcid.org/0000-0002-3368-7297 \\ Minin Nizhny Novgorod State Pedagogical University, Nizhny Novgorod, Russia.
}

Recibido: $1 / 08 / 21$

Aceptado: 30/10/21

\section{Abstract}

Purpose of the article is to analyze the influence of electronic visualization tools on the growth of students' cognitive activity. En el estudio participaron were 108 students aged from 17 to 21 . Students were asked to participate in a survey that allowed them to identify popular electronic resources that provide visualization in education. The survey was conducted with C. D. Spielberger method to study the level of cognitive activity before the use of electronic visualization tools and in the process of their use. The study showed that the use of electronic visualization tools helps to increase attention, students' cognitive activity and reduces fatigue. Modern electronic visualization tools contribute to the students' emotional memory development and form professional competencies.

Key Words: high education, online learning, visualization, interaction, cognitive abilities. 


\section{Resumen}

El objetivo del artículo es analizar la influencia de las herramientas de visualización electrónica en el crecimiento de la actividad cognitiva de los estudiantes. En el estudio participaron 108 estudiantes de entre 17 y 21 años. Se solicitó a los estudiantes que participaran en una encuesta que les permitió identificar los recursos electrónicos populares que brindan visualización en la educación. La encuesta se realizó con el método C. D. Spielberger para estudiar el nivel de actividad cognitiva antes del uso de herramientas de visualización electrónica y en el proceso de su uso. El estudio mostró que el uso de herramientas de visualización electrónica ayuda a aumentar la atención, la actividad cognitiva de los estudiantes y reduce la fatiga. Las herramientas modernas de visualización electrónica contribuyen al desarrollo de la memoria emocional de los estudiantes y forman competencias profesionales.

Palabras clave: educación superior, aprendizaje en línea, visualización, interacción, habilidades cognitivas.

\section{Introduction}

The current changes in the course of scientific and technological progress require certain skills from students (Voronkova et al., 2020). They need to understand each unit of educational material to determine the interaction between structural and informational blocks to be flexible using them in a dynamically changing world. Here you can see the connection between the analysis of education material patterns in the process of knowledge acquisition and in the development of students' skills and abilities.

Organizing educational process, the teacher should draw students' attention to the material being studied. Students' attention activation is one of the important conditions for an effective learning process (Dobudko et al., 2019). Students with a high level of motivation are set up to memorize educational information, but they can be distracted. The low level of motivation among students shows a low interest in the learning process, which creates a problem when presenting the material. In this case, it is important to find the ways to attract students' attention, aimed at increasing interest in the disciplines study. Within the framework of the "Education" National Project, the education system development is held through the material and technical base renewal and educational organizations are provided with modern equipment. The federal project "Digital Educational Environment" is focused on the digital transformation of the education system. Digital services and content development within educational organizations will improve students' professional competencies, increase their cognitive activity and independence.

A modern person, who has digital way of thinking, receives a large amount of information from various sources and some information is perceived superficially. In this case, data 
visualization can increase the efficiency of meaningful reading. High-quality visualization simplifies and accelerates the understanding of complex information.

Active use of electronic learning tools has become a natural element of the educational process (Akvazba et al., 2019). Computer modeling programs have the ability to visualize the material that is difficult for students to understand. Simulation programs allow you to conduct virtual experiments, and educational computer games increase the level of knowledge assimilation. Information technologies allow students to immerse themselves in their future professional activity. Electronic visualization tools change the educational space, updating and expanding the information flow. Students learn to assimilate information independently in the process of interaction with technical means.

Visualization allows you to diversify the learning process, including in professional education, where the emphasis is on verbal interaction. Visualization in education has a positive impact on the participants' interaction in the learning process and promotes rational and emotional enrichment (Aniskin et al., 2020).

The use of electronic visualization tools is aimed at improving training effectiveness due to the educational process automation; it helps to create an individual educational trajectory and provides a verbal and figurative way of transmitting information.

The positive effect of the electronic visualization tools usage is associated with the growth of students' cognitive activity due to obtaining information through sensory perception channels (Ponachugin \& Lapygin, 2019). Students are involved directly in the learning process and use visualization to solve practical learning problems. Electronic visualization tools allow students to recall the required educational material blocks for correcting their educational trajectory (Braslavska \& Rozhi, 2020). The effect is also associated with the teacher's role change; it transforms from the "transmitting information" category to the independent discipline study organization assistant category.

\section{Theoretical framework}

Educational environment elements change using various visualization tools. S. V. Aranova claims that the competencies necessary for a successful life are expanded due to the spread of visual activity products. The author is convinced that at present there is a need to develop a pedagogical concept of educational material visualization as a XXI century phenomenon. This phenomenon is associated with competencies related to visual literacy, skills of creating and understanding information in a visual form. Aranova raises the question of a special information visualization culture formation among students (Aranova, 2019). Mastering this culture will allow students to solve communication problems and to develop their personality as a whole.

A. Skulmovsky, G. D. Ray in their visualization studies express the opinion that educational material which is more difficult to perceive holds the students' attention better. Students are focused on understanding the information and make more effort to 
comprehend it. However, the other studies made by these scientists have shown low efficiency of using realistic details. The authors consider them unnecessary mental workload. Comparing two contradictory results, they came to the conclusion that highly detailed visualization provides high storage performance under the color coding condition. Low detail reduces the effectiveness of training, even in case of color coding. The results of the study indicate that realistic visualization requires appropriate visual aids in order to be effective (Skulmowski \& Rey, 2018).

M. Netel, S. Griffith, O. Delaney, T. Sanders, F. Parker, B. Cruz, K. Lonsdale analyzed the influence of video on the educational process in high educational institutions. They found various studies that measured the videos learning effects among students. After checking all the studies, they came to the conclusion that the replacement of existing teaching methods with video led to small improvements in student learning $(g=0.28)$. Adding video to existing training resulted in significant learning benefits $(g=0.80)$ (Noetel et al., 2021).

C. Chen, M. Wang, P. Kirshner, C. Tsai in their meta-analysis summarized the results of research on the impact of computer-based collaborative learning (CSCL) based on its three main elements: collaboration, computers usage and the use of additional learning environments or tools or auxiliary strategies in CSCL. In the study the authors found that cooperation has a positive effect on the knowledge acquisition (ES [effect size] $=0.42$ ), the skills mastering $(E S=0.64)$ and students' perception $(E S=0.38)$ in computer learning. Secondly, the use of a computer led to a positive impact on the knowledge acquisition $(E S=0.45)$, the skills mastering $(E S=0.53)$, the students' perception $(E S=$ $0.51)$, the group tasks performance $(E S=0.89)$ and social interaction $(E S=0.57)$ in the context of co-education. Third, the use of additional learning tools gave an average effect for gaining knowledge $(E S=0.55)$ (Chen et al., 2018).

F. Stebner, T. Kuhl, T. N. Hoeffler, J. Wirth, A. Ayres consider the role of animated information and static images in their research. The students were divided into two educational environments, characterized by a combination of visualization. The results showed that visualization is necessary for deep information understanding. Moreover, the experiment showed the superiority of animated material over static images (Stebner et al., 2017).

A.V. Kalinichenko considers electronic visualization tools development issue in his research. Designing electronic tools, she took into account the principles indicated in Figure 1. 

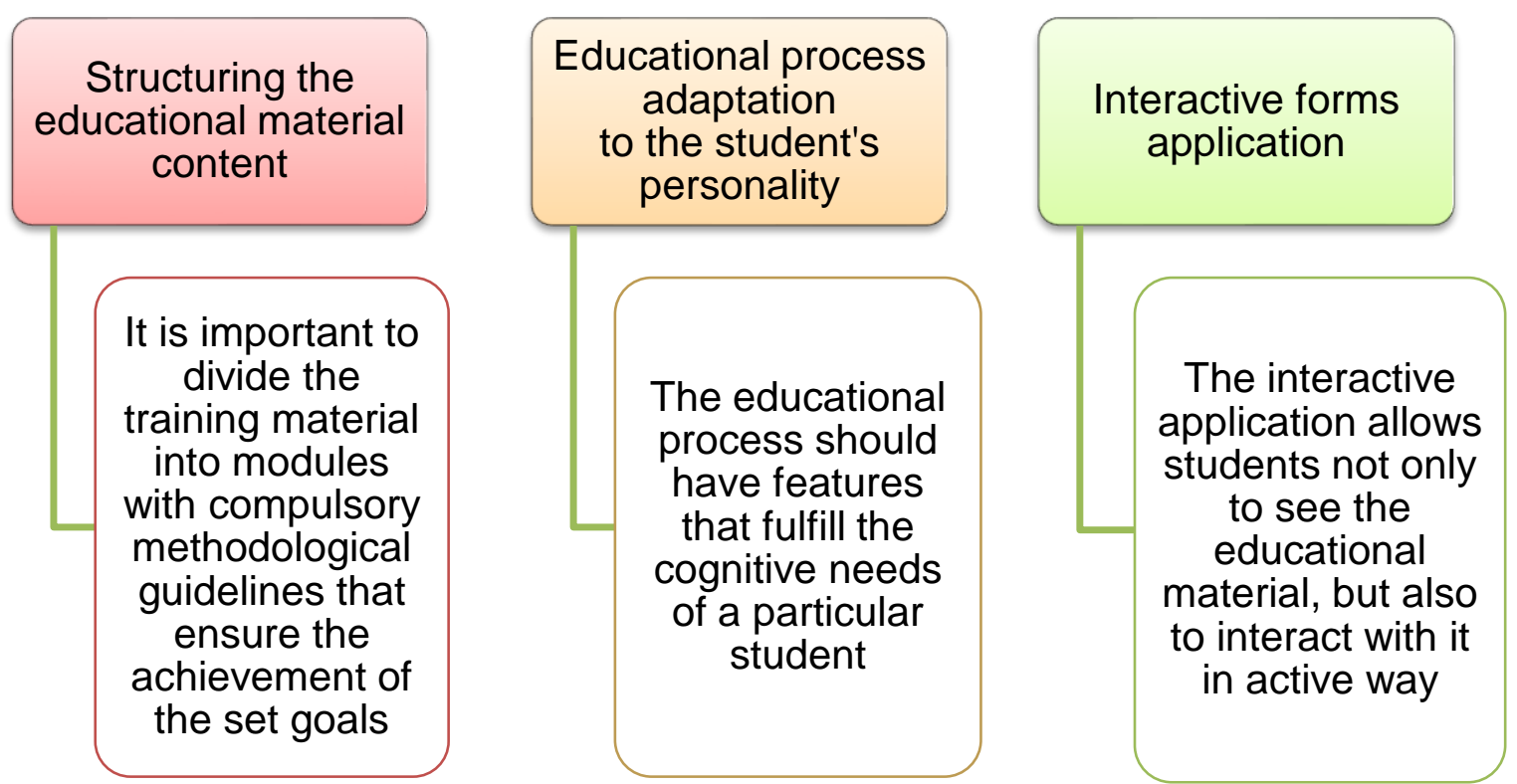

Fig. 1. Principles of electronic visualization tools design (The drawing was developed by the author and is based on the analysis of the works of A.V. Kalinichenko)

Structuring the content of the training material assumes that the training material should be divided into modules. These modules should be completed blocks of educational material. They should contain methodological guidelines that ensure the achievement of didactic goals. The modular approach to the electronic tools design provides flexibility in the educational material content, provides students with favorable conditions for the implementation of independent activities at an individual pace for each. When choosing an electronic service, it is important to take into account students' motivation to interact with educational materials.

The educational process adaptation to the student's personality is reflected in the fact that the learning process must have features that meet the cognitive needs of a particular student.

The use of interactive forms with students should be aimed at the development of personality cognitive structures (Kalinichenko, 2017). The interactive application provides cognitive activity through action. The student not only sees the information, but also acquires a new experience.

Electronic visualization tools ensure the active students' involvement in the learning process not only for obtaining information, but also for the subsequent knowledge use. When you choose specific visual tools it is important to take into account some aspects (Kiseleva et al., 2019). Firstly, the educational process effectiveness increases if the visibility in the learning process performs not only an illustrative, but also a cognitive function. Secondly, the development of didactic tools taking into account the individual characteristics provides the most successful personal visual capabilities usage. 


\section{Methodology}

The study was conducted in 2020-2021. The participants were 108 students aged from 17 to 21 . Students were asked to participate in a survey that allows them to identify popular electronic resources that provide visualization in education. Electronic visualization tools were presented as a choice: time line, cluster, word cloud, crossens, interactive poster, intelligence map, scribing, infographics.

In order to study the level of cognitive activity before the use of electronic visualization tools and in the process of their use, a survey was conducted among students using $C$. D. Spielberger method. Students were offered statements that people use when telling about themselves. They had to mark the number from 1 to 4 , depending on their condition in the learning process. The following statements were proposed: "I want to learn, understand, get to the heart of it", "I am curious", "I feel like a researcher", "I feel that my mind is working well".

Throughout the study, the subjects were under the supervision of experts who recorded the cognitive activity features and student's independence.

\section{Results and discussion}

Visualization is an intermediate link between the educational material and the results of educational activities (Gilyazova, 2020). It is a kind of mechanism that allows you to optimize the learning process. Electronic visualization tools allow students to organize and quickly analyze the information received (Yarygin et al., 2019). Students have the opportunity to see the information in its entirety. Electronic visualization tools help to cover a large amount of information quickly and present the material in a memorable form.

During the study, students were asked to choose electronic visualization tools based on the following characteristics: the ability to add audio and video materials, the convenience of using an application or service, a wide selection of components for converting information. The results of the students' survey are shown in Figure 2. 


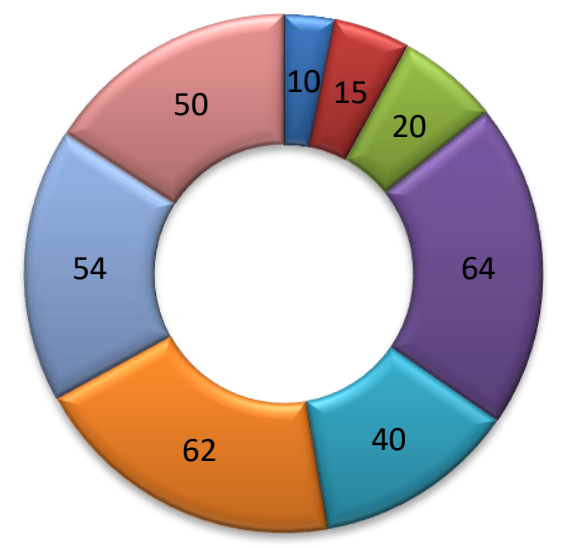

$\square$ Crossens

a Cluster

$\square$ Word Cloud

口Time Line

Interactive poster

$\checkmark$ Intelligence card

$\square$ Scribing

$\square$ Infographics

Fig. 2. Results of a students' survey on the electronic visualization tools choice (The drawing was developed by the author) ${ }^{\star *}$

The results obtained lead to the conclusion that students have the most interest in using the following electronic visualization tools in online learning: time line (64\%), intelligence map $(62 \%)$, scribing $(54 \%)$, infographics $(50 \%)$, interactive poster $(40 \%)$. The low respondents' results on the use of crossens $(10 \%)$, clusters $(15 \%)$, word clouds $(20 \%)$ in the educational process indicates that these tools do not meet the stated requirements.

The time line is a visual image of how a particular event developed in the sequence. Modern online resources allow students to use not only text, but also audio and video materials on the time line (Gorbunova et al., 2020). The Sutori service allows you to string information on a vertical axis, along which the reader moves down. The electronic service allows you to tell various stories, but visually everything looks like a chronological project. Intelligence maps are a graphical way of describing ideas and concepts in the form of a map consisting of key and secondary topics. This electronic tool allows you to work with large amounts of information, conduct brainstorming sessions (Kharytonov et al., 2019).

Online service Draw.io allows you to choose the most suitable one from the available templates (Malakhova \& Bokova, 2020). You can change shapes, text color and background. The intelligence card can be shared with anyone (Tareva \& Tarev, 2020).

Scribing implements the effect of parallel passage, when both auditory and visual receptors are fixed on the provided material (Kirillova et al., 2021). The creation of vivid images causes the listener to have visual associations with the spoken speech, which ensures a high percentage of information assimilation. The PowToon service will help you create animated videos. In the process of preparing materials, you can use text animation, use infographic elements (Samerhanova, 2019). 
Infographics is the way of presenting information. The principles of infographics are content, lightness, imagery. The Canva service is one of the most convenient infographic designers. On the site you can find many different infographic templates for various purposes. Special images and animations, fonts, transparent backgrounds attract and hold the students' attention to the material study (Tsarapkina et al., 2021).

An interactive poster contains interactive elements that implement navigation. It allows you to display the necessary information in text and audio form (Shcerbakova \& Shcerbakova, 2019). Online service Genial.ly will help you create beautiful interactive content to achieve high educational results (Popov et al, 2020). When creating an interactive poster, you can attach web resources, text, video, audio materials. Its advantage over other services is the ability to create multi-page posters.

All electronic visualization tools were analyzed in the study and we found out that the use of electronic tools set will have a positive impact. The integrated use of electronic tools will allow diversifying the educational process and focusing students' attention on the information being studied.

A survey was conducted among students using C. D. Spielberger method to study the level of cognitive activity before the electronic visualization tools use and in the process of their use. Students were offered statements that people use when telling about themselves. They had to mark the number from 1 to 4 , depending on their condition in the learning process. The following statements were proposed: "I want to learn, understand, get to the heart of it", "I am curious", "I feel like a researcher", "I feel that my mind is working well". The results are shown in Figure 3.

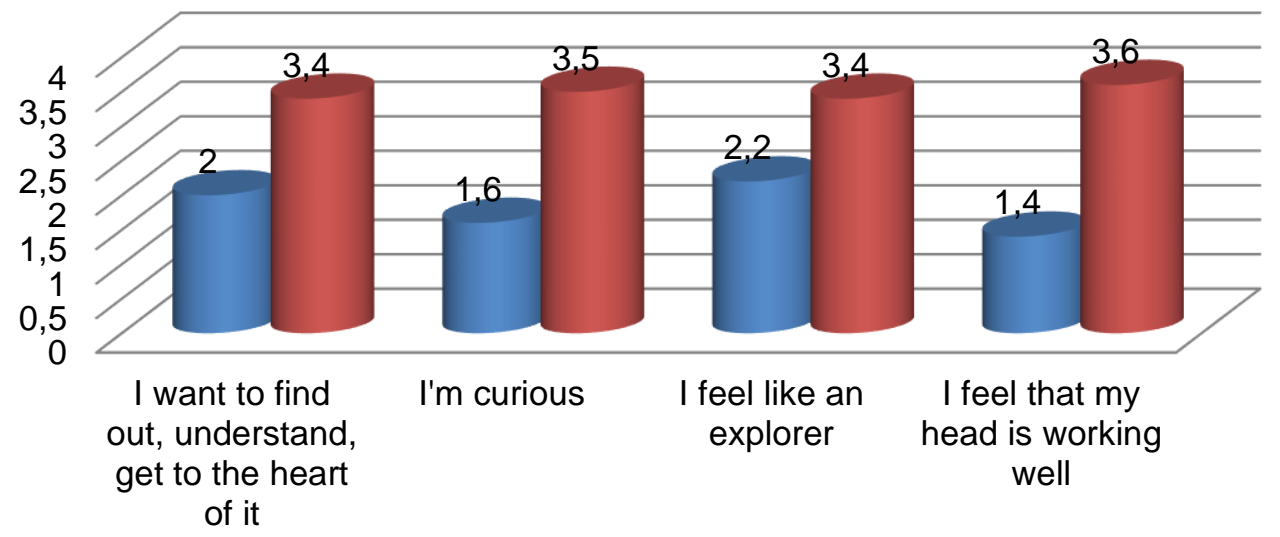

- The average result of the survey before the use of electronic visualization tools

- The average result of the survey during the use of electronic visualization tools

Fig. 3. The results of the students' survey using C. D. Spielberger method (The drawing was developed by the author) 
Students observation in the process of using electronic visualization tools has shown that the educational process contributes to increasing students' attention and activity and reduces fatigue. There is a noticeable increase in cognitive activity. The use of electronic visualization tools helps to learn the material and to solve educational tasks in creative manner.

\section{Conclusion}

The modern education system modernization is carried out on the basis of the widespread use of information and communication technologies. They represent innovative perspectives and opportunities for organizing an effective educational process. An important direction of using electronic tools is the use of learning visualization capabilities by increasing visibility and combining logical and imaginative ways of mastering educational material.

Modern electronic visualization tools contribute to the development of students' emotional memory and form professional competencies. It is possible to achieve educational goals not by obtaining information, but by using various methods of working with it. This includes getting information, its systematization, processing, data exchange, aesthetic design, and results presentation. Electronic visualization tools help to cope with these requirements easy enough.

\section{Bibliographic references}

Akvazba, E., Bogdanova, V., Uzlova, N., \& Patrusheva, I. (2019). Problems and prospects of the Russian information society. Amazonia Investiga, 8(20), 310-322. Retrieved from https://amazoniainvestiga.info/index.php/amazonia/article/view/144.

Aniskin, V. N., Korostelev, A. A., Lvovna, B. A., Kurochkin, A. V., \& Sobakina, T. G. (2020). Teaching potential of integrated learning technologies Smart, Stem and Steam. Revista De La Universidad Del Zulia, 11(29), 328-336.

Aranova S. V. (2019). Problemas culturales de visualización de información educativa. Chio, №4 (61), 55-60.

Arbeláez-Campillo, D., Tatsiy, V., Rojas-Bahamón, M., \& Danilyan, O. (2020). Contributions of critical thinking as a form of participation and political deliberation. Amazonia Investiga, 9(27), 5-12. https://doi.org/10.34069/Al/2020.27.03.1

Braslavska O. V., \& Rozhi I. G. Peculiarities of innovative learning in a modern educational environment. (2020). Balkan Scientific Review, 4, 2 (8), 24-26.

Chen, J.J. \& Wang, M., Kirschner, P. \& Tsai, Ch.Ch. (2018). The Role of Collaboration, Computer Use, Learning Environments, and Supporting Strategies in CSCL: A Meta-Analysis. Review of Educational Research. 88, 799-843. DOI: 10.3102/0034654318791584.

Dobudko T.V., Korostelev A.A., Gorbatov S.V., Kurochkin A.V., Akhmetov L.G. (2019). The organization of the university educational process in terms of digitalization of education. Humanities and Social Sciences Reviews. 7(4), pp. 1148-1154. 
Gilyazova, O. (2020). Gaming practices and technologies in education: Their educational potential, limitations and problems in the world-of-work and world-of-play context. Revista Tempos e Espaços em Educação, 13(32), 1-23. https://doi.org/10. 20952/revtee.v13i32.14276.

Gorbunova, N.V., Vaganova, O.I., Zhivoglyad, M.V., Snurnitsyna, J.M., \& Sergeeva, M.G. (2020). Design of Course Content in the Digital Environment of Vocational Education. International journal of applied exercise physiology, 9, 11 14-20.

Kalinichenko A. V. (2017). Herramientas didácticas electrónicas interactivas con imágenes cognitivas. Boletín Científico-técnico de tecnologías de la información, mecánica y óptica, 2, 359-364.

Kharytonov, E., Kharytonova, O., Tolmachevska, Y., Fasii, B., \& Tkalych, M. (2019). Information Security and Means of Its Legal Support. Amazonia Investiga, 8(19), 255-265. https://amazoniainvestiga.info/index.php/amazonia/article/view/227

Kirillova I.K., Zubkova Y.V., Tsarapkina Ju.M., Ilyasova A.V., Rubinchik Y.S. (2021). Modern electronic systems in the organization of training webinars. Revista Eduweb, de Tecnología de Información y Comunicación en Educación, 15(1), pp. 39-48.

Kiseleva, O., Lebedev, A., Pinkovetskaia, I., Rojas-Bahamón, M., \& Arbeláez Campillo, D. (2019). Specialization and concentration of small and medium enterprises employees: Russian data. Amazonia Investiga, 8(20), 6-15. Retrieved from https://amazoniainvestiga.info/index.php/amazonia/article/view/59.

Malakhova, V.G., \& Bokova, T.N. (2020). Philosophical ideas of postmodernism and their impact on the education system in Russia and the USA. Education and Self Development, 15(1), pp. 93-103.

Noetel, M., Griffith, S., Delaney, O., Sanders, T., Parker, P., del Pozo Cruz, B., \& Lonsdale, C. (2021). Video Improves Learning in Higher Education: A Systematic Review. Review of Educational Research. 91, 204-236. DOI: 10.3102/0034654321990713.

Pinkovetskaia, I., Kryukova, L., Arbeláez, D., \& Rojas-Bahamon, M. (2019). Female Entrepreneurship: Types of Economic. Activity. Tarih kultur ve sanat arastirmalari dergisi-journal of history culture and art research, 8(2), 253-265. DOI: 10.7596/taksad.v8i2.2153

Ponachugin, A.V., \& Lapygin, Yu.N. (2019). Digital Educational Resources of the University: Design, Analysis and Expertise. Vestnik of Minin University, 7(2), 5. (in Russ).

Popov M.N., Vaganova O.I., Lapshova A.V., Kirillova I.K., Chelnokova E.A. (2020). The use of messengers in organizing the interaction of university students. International Journal of Applied Exercise Physiology, 9 (11), pp. 83-88.

Samerhanova, E.K. (2019). Formation of competences in the field of mathematical modeling among teachers of vocational training in the conditions of the information and educational environment of the university. Vestnik of Minin University, 2 (27), p. 1-7. Available at: DOI: 10.26795/2307-1281-2019-7-2-4. Access: May 23, 2021. Shcerbakova E.V., \& Shcerbakova T. N. (2019). Experience of Use of Remote Computer Technologies at The Organization of Independent Work of Students in The 
Conditions of a Mark and rating system. Baltic Humanitarian Journal. (Baltic Humanitarian Journal), Vol. 8, No 4 (29), pp. 192-195.

Skulmowski A., \& Rey, G. D. (2018). Realistic details in visualizations require color cues to foster retention. Computers \& Education. 122, 23-31. https://doi.org/10.1016/j.compedu.2018.03.012.

Stebner F., Kühl T., Höffler T. N., Wirth J., Ayres P. (2017). The role of process information in narrations while learning with animations and static pictures. $\begin{array}{llll}\text { Computers \& } \quad \text { Education, } & \text { 104, }\end{array}$ https://doi.org/10.1016/j.compedu.2016.11.001.

Tsarapkina, J. M., Plahina, L. N., Konoplyuk, N. V., Vaganova, O. I., Lapshova, A. V. (2021). The formation of bachelors' digital competencies at the university. Propositos y representaciones, 9, № SI, Article number e811.

Tareva, E.G., \& Tarev, B.V. (2018). The assessment of students' professional communicative competence: New challenges and possible solutions. XLinguae, 11(2), pp. 758-783.

Voronkova, V., Nikitenko, V., Teslenko, T., \& Bilohur, V. (2020). Impact of the worldwide trends on the development of the digital economy. Amazonia Investiga, 9(32), 81-90. https://doi.org/10.34069/Al/2020.32.08.9.

Yarygin O.N., Korostelev A.A., Akhmetov, L.G., Maseleno, A. (2019). Modeling of competence as a tool of goal setting for education in modern society. International Journal of Recent Technology and Engineering, 7(6), pp. 72-77. 